\title{
Constructing and disrupting Ireland's industrial development authority
}

\section{Construindo e interrompendo a autoridade irlandesa de desenvolvimento industrial}

\author{
Dr. Paul F. Donnelly ${ }^{1}$
}

\begin{abstract}
Actor-network theory is considered to have great potential for broadening and deepening our grasp of institutional work (LAWRENCE; SUDDABY, 2006). Given its focus on process, ANT offers a means to breathe life into the practices associated with institutionalization. With Callon's (1986) four moments of translation as analytical lens, and with Ireland's Industrial Development Authority as empirical example, I seek to address the concerns of Clegg and Machado da Silva (2009) by reconsidering "the role of agency, power, persistence and change in the process of institutionalization".
\end{abstract}

Keywords: actor-network theory, industrial development, institutionalization, Ireland.

\section{Resumo}

Considera-se que a teoria ator-rede tem um grande potencial para ampliar e aprofundar nossa compreensão do trabalho institucional (LAWRENCE; SUDDABY, 2006). Dado o seu foco no processo, a teoria oferece um meio para dar vida às práticas associadas à institucionalização. Tendo os quatro momentos de tradução de Callon (1986) como lente analítica e a Autoridade de Desenvolvimento Industrial da Irlanda como exemplo empírico, buscou-se responder às preocupações de Clegg e Machado da Silva (2009), reconsiderando-se "o papel da agência, do poder, da persistência e da mudança no processo de institucionalização".

Palavras-chave: teoria ator-rede, desenvolvimento industria, institucionalização, Irlanda.

\section{Introduction}

While Ireland's "economic miracle" has stalled in the wake of the current global crisis, it was in the midst of crisis that a new social reality emerged from the 1940s, which translated into the development that underpinned the so-called "Celtic Tiger". In keeping with the theme of LAEMOS 2010, that of constructing and disrupting social realities, the tale in this paper follows the institutionalization of Ireland's Industrial Development Authority (IDA) and the organizational field of industrial development.

Through the contributions of actor-network theory (ANT), I seek to address concerns noted by Clegg and Machado da Silva (2009) to reconsider "the role of agency, power, persistence and change in the process of institutionalization". Specifically, the paper seeks to address the historicity of institutions and their change, legitimation and de-legitimation, institutionalization and de-institutionalization, and overcoming the dualism of structure and agency. It is in following the actor-networks that we can come to explore how it is that institutionalization is produced, without having to assume from the outset that which we are looking to study (COOPER; LAW, 1995), and that we may more clearly see the "complexity of historical becoming" (TOURRAINE, 1988, p.11).

Paper received in April 2010 and accepted for publication in June 2010.

${ }^{1}$ Is a lecturer in organization studies and international business at the Dublin Institute of Technology, Ireland. He received his PhD from the University of Massachusetts at Amherst, USA. A Fulbrighter, he is Vice President (2009-11) and President-elect (2011-13) of the Irish Fulbright Alumni Association. Prior to academia, he worked in various middle management roles with the Irish public sector telecommunications company, Telecom Eireann (now privatized and called Eircom). Address: Dublin Institute of Technology, College of Business, Dublin Institute of Technology Aungier Street (3-062), Dublin 2, Ireland. E-mail: paul.donnelly@dit.ie. 


\section{Following institutionalization with actor-network theory}

ANT is considered to have great potential for broadening and deepening our grasp of institutional work (LAWRENCE; SUDDABY, 2006). Given its focus on process, ANT offers a means to breathe life into the practices associated not just with institutionalization, but also de-institutionalization, rather than concentrate on institutions as reified structures (TOLBERT; ZUCKET, 1996).

In addressing institutionalization, ANT focuses on investigating how the institutional is "performed", how materials of all sorts are "disciplined, constituted, organised, and/or organising themselves" (LAW; HETHERINGTON, 1999, p.6). At the core of the approach lies

a concern with how actors and organisations mobilise, juxtapose and hold together the bits and pieces out of which they are composed; how they are sometimes able to prevent those bits and pieces from following their own inclinations and making off; and how they manage, as a result, to conceal for a time the process of translation itself and so turn a network from a heterogeneous set of bits and pieces, each with its own inclinations, into something that passes as a punctualised actor. (LAW, 1992, p.6)

Thus, through the "study of order building or path building" (AKRICH; LATOUR, 1992, p.259), I seek to illustrate the precariousness of institutionalization that is hidden by institutional theory; institutionalization does not exist outside its performance. I use Latour's (1991, 1999) program/anti-program mapping and Callon's (1986) four moments of translation (problematization, interessement, enrollment and mobilization) to illustrate institutionalization as a succession of translations, where the focus is on the actors enrolled and mobilized, on material heterogeneity, on actors performing relationally, and on contingency.

For neo-institutionalists with an interest in understanding how institutions are created, sustained and disrupted, ANT offers insights and contributions in three key areas, namely, through moving from reification to relationality, from diffusion to translation and from power as property to power as product (LAWRENCE; SUDDABY, 2006).

\section{Institutionalization as relational effect}

ANT provides a good canvas on which to paint "the discriminations that are performed and the boundaries that are constructed in the activities it studies" (LEE; HASSARD, 1999, p.392). Through this approach, the analytical focus is relational and process-oriented, treating, for example, institutions and organizations as precarious, interactive effects, which are generated, heterogeneous, patterned, uncertain and contested in character (LAW, 1992).

At the heart of ANT is the metaphor of heterogeneous networks (LAW, 1992) where, for example, institutionalization is the result of much hard work in which various bits and pieces, human and nonhuman, are juxtaposed into a network configuration that surmounts their individual resistances. Said another way, institutionalization is both a material matter and a question of arranging and ordering those materials.

An actor is an effect generated in a heterogeneous network, such that, as implied by the term actor-network, an actor is always a network (LAW, 1992). Hence, "[a]n actor-network is simultaneously an actor whose activity is networking heterogeneous elements and a network that is able to redefine and transform what it is made of" (CALLON, 1987, p.93). Thus, beginning with a flat terrain, absent any dualisms, the actor-network approach serves to bypass the agency/structure distinction common to much social theory (LATOUR, 1986; STRUM; LATOUR, 1987), such that actors derive their intentionality and identity from the network, and not as independent agents.

For ANT, all materials, human and nonhuman, have the characteristics they do as a consequence of their relations with other materials. ANT, therefore, is also understood in terms of relational materiality and performativity. In the case of the former, it employs a material semiotics whereby entities, human and nonhuman, assume their form and take on their characteristics as a consequence of their relations with other actors (AKRICH; LATOUR, 1992; LAW, 1999; LAW; HETHERINGTON, 1999). Akrich and Latour's (1992, p.259) redefinition of ANT as a semiotic theory of material assemblies reclaims a more general "nontextual and 
nonlinguistic interpretation" of semiotics as meaning "how one privileged trajectory is built, out of an indefinite number of possibilities". Thus, defining semiotics as the "study of order building or path building" (AKRICH; LATOUR, 1992, p.259) broadens its meaning to encompass the orderings of material things.

For Law and Hetherington (1999), a material semiotics has to do with materiality in the sense the institutional is created in circumstances that are materially heterogeneous, and it is a semiotics in that it assumes the institutional, along with what goes into producing the institutional, acquires its meaning and significance because of how everything interacts together, not because of its essential characteristics or qualities. Through seeking to understand how institutions are created, maintained and disrupted, therefore, a semiotics of materiality refuses the division between human and nonhuman, in addition to any prior judgment as to what counts as important or not, in favor of looking at the entire range of heterogeneous bits and pieces that go into the institutional (LAW; HETHERINGTON, 1999).

It is here that the notion of performativity enters into play (LATOUR, 1986; LAW, 1999; LAW; HETHERINGTON, 1999; STRUM; LATOUR, 1987). In constituting the contingent, emergent phenomenon that we may come to call an institution (if at all), materials of all sorts "are being disciplined, constituted, organised, and/or organising themselves" (LAW; HETHERINGTON, 1999, p.6). As a creation, an effect produced within heterogeneous relations, the material outcome that we (may come to) identify as an institution does not exist outside its performance. The institutional is an achievement as a result of performing the relations in which it is situated; it is how such performance is achieved that is of interest to ANT. It is precisely because the institutional is nothing more than relational effects that it is important to study how it is produced (LAW, 1999; LAW; HETHERINGTON, 1999).

Therefore, in moving from attending to the reified elements of institutions towards seeing institutions as relational effects (LAW, 1992), an ANT approach draws attention to the ongoing and dynamic interactions that go into producing and contesting what we come to see as the outcomes of institutional work. For example, rather than tracking isomorphism through time and space, institutional researchers adopting an ANT perspective would focus on exploring the processes of interaction through which isomorphism emerges, is reproduced and contested.

Seen thusly, ANT provides those engaged in institutional work with a means of addressing the issue of how to empirically investigate a phenomenon unavailable to conscious perception (LAWRENCE; SUDDABY, 2006, p.242). As things stand with traditional institutional work, it is only when institutions are being created or destroyed that the agency underlying institutional work becomes most visible and accessible, for it is here that the taken-for-grantedness is exposed. Outside of this, during periods when institutions have become reified and are apparently stable, neo-institutional research is faced with the problem of how to account for such stability.

ANT provides a way out of this dilemma through focusing on how different networks are built around competing programs of action that generate outcomes, instead of being distracted by outcomes alone. As such, through problematizing the widely shared view of institutions as concrete and enduring social structures, in addition to reminding those engaged in institutional work that the very institutions and organizations they study "are fictions actively created and re-created by actors" (LAWRENCE; SUDDABY, 2006, p.242), ANT is well placed to facilitate a broadening and deepening of our understanding of institutional work.

\section{Institutional work as translation}

From an ANT perspective, much organizational theorizing engages in the practice of purification, which requires categorization and classification, and it is through purifying that institutions can be identified. They can be classified and categorized according to an abstract set of features, such that they are rendered static, permanent, timeless, universal and, above all, knowable. In being purified, they become ideal-types against which to measure and verify that which pertains to them. But the question is, in order to purify, what has the knowledge-making enterprise left out? To focus on the practice of purification is only part of the story, for there is another practice, that of translation, on which much of our theorizing depends for its existence and yet which it denies at the same time (LATOUR, 1993). 
Concurrent with purifying the messy world in which we live, we also engage in translation. Here, far from separating everything into neat categories, their contacts are amplified, mixing together humans and nonhumans, without bracketing anything and without excluding any combination, in the process creating hybrids in the form of networks of humans and nonhumans. Different from the practice of purification, which involves separation, the practice of translation involves the threading together of any or all of these actors into a network that makes sense. It entails interconnecting these heterogeneous elements and viewing them as performing relationally, as interacting to produce what we contingently call an institution, with one actor seeking to redefine the meaning of the other actors, enrolling them into a position, such that its interests also become theirs. What results from the practice of translation are hybrids, networks that are both contingent and emergent. They are contingent in that their relations are never fixed for all time, such that the actor-networks could come asunder should the interests of any actors diverge. Similarly, they are emergent in that they do not appear ready formed, as pure essences that always-already existed.

In focusing more on "the processes through which discretion emerges" and less on "the problem of giving accurate descriptions of discrete elements" (LEE; HASSARD, 1999, p.398-9, emphasis in original), the empirical for ANT becomes the site of "active processing" where not only are the descriptions of the institutional being worked and reworked by actors, both human and nonhuman, but so too is the institutional itself. In addressing the institutional, therefore, ANT focuses its efforts on investigating how the institutional is "performed".

Moving away from diffusion, ANT's concept of translation affords researchers looking to move past the totalizing view of institutions and institutional outcomes with both a conceptual and methodological means to advance their work. Thus, rather than trace diffusion across space and time, an ANT approach attends to the local motivations for adopting isomorphic templates, norms or practices, for example, and to local variations in the use and outcomes of adopting these isomorphic templates, norms or practices. What ANT avoids assuming is that all actors within an emerging network act in a similar way and for similar reasons. Indeed, different actors not only take on similar templates, norms or practices for different reasons, but, in the process of adoption, they also introduce slight changes to them (SAHLIN-ANDERSSON, 1996). Therefore, a key difference between diffusion and translation is that diffusion is interested in the movement of, for example, a blackboxed organization through time and space; translation calls attention to the work of constructing the organizational and to the shifting associations and substitutions.

\section{Power as product of network interactions}

Viewed through an ANT lens, power is conceptualized as a network effect: it "is not something you can hoard and possess, it is something that has to be made" (LATOUR, 1986, p.274, emphasis in original), where the focus is on processes of enrollment and translation. As Murdoch notes (1995, p.748), "those who are powerful are...those able to enrol, convince, and enlist others into networks on terms which allow the initial actors to 'represent' the others".

Thus, by way of a third contribution to the study of institutional creation, reproduction and demise, ANT facilitates those doing institutional work in moving away from conceiving of power as property towards seeing it as the product of network interactions (CALLON; LATOUR, 1981): power is not the preserve of any individual actor with a network, rather it is distributed and it is the collective interaction of actors within a network that produces power. Seeing power thusly, that is, as a distributed process, moves the focus away from the locus or agents of change, for example, towards how actor-networks grow in size, complexity and power and draws on Callon's (1986) process of translation, namely, problematization, interessement, enrollment, mobilization. It moves the focus away from power used to mobilize resources within an institutional field towards attending to how institutions are created and contested, which, in turn, defines the resources and actors comprising the field. ANT affords a political perspective of power, where institutions appear as powerful and stable structures because of the actors holding together in a network and not because of their material or intrinsic nature. Power and agency are products of an actor-network that has become (temporarily) stabilized or blackboxed. 


\section{Doing actor-network theory}

The empirical underpinning this work is Ireland's IDA, an agency established by the Irish government in 1949 to foster the country's indigenous industrial development. Over the years, the organization's brief was changed to attracting foreign direct investment (FDI), before being given complete operational autonomy as a semi-state body with national responsibility for both FDI and indigenous industrial development.

In terms of the data, I had recourse to both archival and interview material. The primary and secondary archival sources to which I had access were those available in the public domain, and included:

\begin{tabular}{lll}
\hline - $\begin{array}{l}\text { Oireachtas (parliament) archives, which cover } \\
\text { debates and questions from the foundation of the } \\
\text { state (1922) to the present. }\end{array}$ & $\begin{array}{l}\text { National Archives, which cover civil service } \\
\text { department records from the foundation of the State } \\
\text { (1922) up to 1976. }\end{array}$ \\
\hline - Media archives. & - & Legislation. \\
\hline - Government-sponsored reports/reviews. & IDA Annual Reports, 1969/70 to 1994. \\
\hline - Government policies and economic programs. & - $\begin{array}{l}\text { Published work (e.g., articles, books, reports, } \\
\text { monographs) relating to the period under study. }\end{array}$ \\
\hline
\end{tabular}

In addition to archival material, I also conducted semi-structured interviews with the three surviving IDA managing directors, who represent key decision-makers with intimate knowledge of the IDA and much of the period under study. The interviews were concerned with such broad areas as: the IDA's creation and evolution, encapsulating the key events, large or small, that shaped its creation and evolution; the IDA's persistence over time; institutional supports and threats; how the organizations was viewed/supported/challenged by government, politicians, the civil service, the media, the public, other government agencies, indigenous industry, foreign investors.

For the purposes of analysis, I first constructed a running chronology of the events so as to begin to get a handle on what I was dealing with. The starting point for the chronology was the period immediately prior to the creation of the IDA as an administrative body in 1949, when the alternative was to continue with the status quo option of the Department of Industry and Commerce, and the end-point marks the restructuring of the IDA into three separate agencies - Forfás, Forbairt (subsequently, Enterprise Ireland in 1998) and Industrial Development Agency Ireland - in 1994. Having constructed the chronology, I then moved to following the actors using Latour's $(1991,1999)$ program/anti-program mapping mechanism (see Figure 1 for an example of such mapping), which serves to illustrate the work of translation, hybrid-creation and purification involved in institutional creation, reproduction and disruption. 
Figure 1: Sample program/anti-program mapping.

\begin{tabular}{|c|c|c|c|}
\hline Vers & Program $\longrightarrow$ & \multicolumn{2}{|c|}{ Anti-program } \\
\hline 12 & $\begin{array}{l}1948 \text { general election / Inter-Party Government / protectionist regime / short-term time horizon } \\
\text { / extensive commitments / political capital / industrial development / Department of Industry and } \\
\text { Commerce }\end{array}$ & \multicolumn{2}{|c|}{$\begin{array}{l}\text { Free trade / foreign competition / European economic boom / industrial } \\
\text { inefficiency / migration from the land / unemployment / emigration/ } \\
\text { balance of payments }\end{array}$} \\
\hline 13 & $\begin{array}{l}1948 \text { general election / Inter-Party Govenment / protectionist regime / short-term time horizon } \\
\text { / extensive commitments / political capital / industrial development / Department of Industry and } \\
\text { Commerce / IDA a 'new conception' }\end{array}$ & \multicolumn{2}{|c|}{$\begin{array}{l}\text { Free trade / foreign competition / European economic boom / industrial } \\
\text { inefficiency / migration from the land / unemployment / emigration/ } \\
\text { balance of payments }\end{array}$} \\
\hline 14 & $\begin{array}{l}\text { Seán MacBride, Minister for Foreign Affairs and leader of Clamn na Poblachta } \\
\text { / proposal / self-sufficiency / industrial development }\end{array}$ & \multicolumn{2}{|c|}{$\begin{array}{l}\text { Free trade / foreign competition / European economic boom / industrial inefficiency / migration } \\
\text { from the land / unemployment / emigration / balance of payments }\end{array}$} \\
\hline 15 & $\begin{array}{l}\text { Sean MacBride, Minister for Foreign Affairs and leader of Clamn na Poblachta / proposal } \\
\text { / self-sufficiency / industrial development / Government / Daniel Morrissey, Minister for Industry } \\
\text { and Commerce/ six-month review of protection and industrial development }\end{array}$ & \multicolumn{2}{|c|}{$\begin{array}{l}\text { Free trade / foreign competition / European economic boom / industrial } \\
\text { inefficiency / migration from the land / unemployment / emigration / } \\
\text { balance of payments }\end{array}$} \\
\hline 16 & \begin{tabular}{l|l} 
Seán MacBride, Minister for Foreign Affairs and leader of Clamn na Poblachta & Free tra \\
/ proposal / self-sufficiency / industrial development / Government / Daniel & unempl \\
Morrissey, Minister for Industry and Commerce / six-month review of protection & enterpri \\
and industrial development / proposal for an IDA & Board/ \\
\end{tabular} & \multicolumn{2}{|c|}{$\begin{array}{l}\text { Free trade / foreign competition / European economic boom / industrial inefficiency / migration from the land / } \\
\text { unemployment / emigration / balance of payments / Department of Finance / hands-off mindset to private } \\
\text { enterprise / profit incentive of private enterprise / not mastermind planners / Industrial Development Advisory } \\
\text { Board / crackpot socialist plammers / business community confidence }\end{array}$} \\
\hline 17 & \multicolumn{2}{|c|}{$\begin{array}{l}\text { February } 12^{\text {th }}, 1949 \text { / Department of Industry and Commerce statement amnouncing Government decision to establish } \\
\text { an Industrial Development Authority and outlining its functions / William Norton, Támiste and Labour Party } \\
\text { leader / party meeting address / speeches by members of Government / interested bodies / newspaper articles }\end{array}$} & $\begin{array}{l}\text { Free trade / foreign competition / European economic boom/ } \\
\text { industrial inefficiency / migration from the land / unemployment / } \\
\text { emigration / balance of payments }\end{array}$ \\
\hline 18 & \multicolumn{2}{|c|}{$\begin{array}{l}\text { February } 12^{\text {th }}, 1949 \text { / Department of Industry and Commerce statement amnouncing Government decision to establish } \\
\text { an Industrial Development Authority and outlining its functions / William Norton, Támiste and Labour Party } \\
\text { leader / party meeting address / speeches by members of Government / interested bodies / newspaper articles } \\
\text { / February } 15^{\text {th }}, 1949 \text { / John A. Costello, Taoiseach / address to Federation of Irish Manufacturers / IDA the } \\
\text { most important industrial development initiative since the foundation of the State }\end{array}$} & $\begin{array}{l}\text { Free trade / foreign competition / European economic boom / } \\
\text { industrial inefficiency / migration from the land / unemployment / } \\
\text { emigration / balance of payments }\end{array}$ \\
\hline 19 & \multicolumn{2}{|c|}{$\begin{array}{l}\text { February } 12^{\text {th }}, 1949 \text { / Department of Industry and Commerce statement amnouncing Government decision to establish } \\
\text { an Industrial Development Authority and outlining its functions / William Norton, Táimiste and Labour Party } \\
\text { leader / party meeting address / speeches by members of Government / interested bodies / newspaper articles } \\
\text { / February } 15^{\mathrm{m}}, 1949 / \text { John A. Costello, Taoiseach / address to Federation of Irish Manufacturers / IDA the } \\
\text { most important industrial development initiative since the foundation of the State / February } 16^{\mathbf{m}}, 1949 \text { / Daniel } \\
\text { Morrissey, Minister for Industry and Commerce / main IDA function to manage protectionism }\end{array}$} & $\begin{array}{l}\text { Free trade / foreign competition / European economic boom / } \\
\text { industrial inefficiency / migration from the land / unemployment / } \\
\text { emigration / balance of payments }\end{array}$ \\
\hline 20 & \multicolumn{2}{|c|}{ 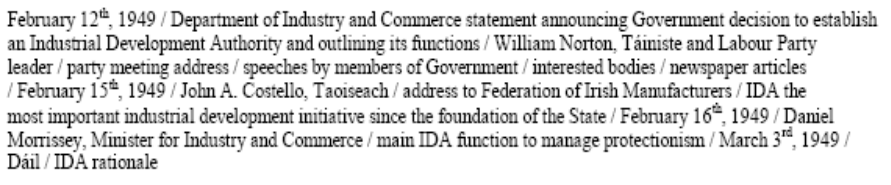 } & $\begin{array}{l}\text { Free trade / foreign competition / European economic boom/ } \\
\text { industrial inefficiency / migration from the land / unemployment / } \\
\text { emigration / balance of payments }\end{array}$ \\
\hline
\end{tabular}

This work done, I then engaged with Callon's (1986) four stages of translation as analytical lens to focus on particular moments in the process of institutionalization. The four "stages" are better understood as overlapping moments in an ongoing and contested process than as clearly demarcated steps toward a final endpoint. The first moment, problematization, the primary actor defines the problem and the set of relevant actors. By defining the problem and the program for dealing with it, the primary actor makes itself indispensable such that it becomes an obligatory passage point for these others attainment of the solution. To problematize in this way is to undertake an endeavor that may or may not be accomplished.

The remainder of the translation process consists precisely of struggles to achieve consensus among all actors regarding this particular definition of problem and solution. Interessement, the second moment, the primary actor recruits other actors to assume roles in the network, roles that recognize the centrality of the primary actor's own role. "Trials of strength" will determine whether the actors, as defined, will "submit to being integrated into the initial plan, or inversely, refuse the transaction by defining [their] identity, goals, projects, orientations, motivations or interests in another manner" (CALLON, 1986, p.207). Through a variety of possible mechanisms, devices and strategies, ranging from simple solicitation to seduction to appeals to rationality to force, interessement projects are concerned with locking actors into the roles proposed for them, blocking out alternative identities, disrupting all possible competing associations, constructing a system of links or alliances among actors, and gaining their commitment.

When successful, interessement validates problematization and the association(s) it implies. It also achieves enrollment, the third moment, in which roles are defined and actors formally accept and take on these roles. Finally, in the fourth moment, mobilization, the primary actor assumes a spokesperson role for passive network actors and seeks to mobilize them to action. This moment owes its name to the necessary movements and displacements that have occurred as previously unrelated actors have come into a chain of association, been rendered available and cooperative, and finally, become silent as the primary actor is now permitted to speak for them. 


\section{Institutionalizing Ireland's industrial development authority}

From immersion in the data to arrive at the initial mapping, I identified what appeared to me to be the key actors to follow (CALLON, 1986) and the programs of action (LATOUR, 1991, 1999). Through several rounds of recursive processes, moving between data, actors, events and connections, focusing on the shifting assemblies of actors, I arrived at what seemed to me a coherent story, one that traces the construction of a trajectory that only appears in retrospect.

In what follows, I tell a tale of times of crisis and development involving the creation, continuation and disruption of both an organization and an organizational field. Neither organization nor organizational field existed prior to their construction; rather they were emergent and contingent. Throughout the telling of the story, actor-networks are in constant flux, with hybrids abounding. To the degree that any of these hybrids achieve stability and become blackboxed it is provisional.

\section{Emerging from an idea - initial problematization}

We enter our story at a point where the blackboxed actor-network of protectionism in Ireland has sought to ensure its continued existence through mobilizing the new coalition government, itself an actor-network, which came to power following the 1948 general election. However, protectionism was facing difficulty, with industrial inefficiency, migration from the land, unemployment and emigration all increasing and the balance of payments deteriorating. Now acting as spokesperson for protectionism, the new government attempted to define the problem as one requiring industrial development built around a new conception, the Industrial Development Authority. On its own, this idea is insufficient to counter the challenge from the "industrial inefficiency / migration from the land / unemployment / emigration / balance of payments" hybrid.

However, from here, we trace the accumulation of actors whose interests are translated and aligned, such that they become enrolled and mobilized into action. With protectionism under threat, members of government posited a new organization, the IDA, as the vehicle through which to achieve a more efficient use of protective measures and independent industrial development. The Department of Finance, as spokesperson for the civil service, initially proved unwilling to back the proposal, preferring instead the laissez faire approach of private enterprise seeking out opportunity. If the proposal were to go ahead, Finance was of the view that it would need to be an advisory board, and not a "gang of crackpot socialist planners", and that it would need to gain the confidence of the business community (LEE, 1989, p.310). Finance's influence would be assured through controlling the staffing of all but the most senior positions.

Having translated the interests of the civil service, government then moved to recruit other key actors. Statements were issued to the media announcing the government's decision to establish the IDA and outlining its functions. Party leaders addressed the party faithful to bring them on side and government ministers addressed leading industrialists through speeches at meetings of the likes of the Federation of Irish Manufacturers, all of which was reported on favorably in the media. In seeking to translate the interests of these key actors, government statements and speeches were all aimed at reinforcing the rationale for, and benefits of, setting up the IDA, while also assuaging any concerns that protection would be removed.

While the proposed IDA's composition was announced in early March 1949, its four whole time members, who were selected for the depth and breadth of their business knowledge and experience and for their extensive contacts (PDDE, v.119, col.1586-1587, 9-March-1950), held their first meeting on May 26th, 1949, marking the IDA's official coming into being as an administrative body with a staff of 13 civil servants (PDDE, v.138, col.545-546, 23-April-1953). In terms of freedom, the IDA members were neither civil servants nor subject to the regulations or procedures of the civil service. Rather, as befitting their autonomous status and their "selfgoverning, flexible type of organisation", they were to have their own offices, staff and funding and they were to "be free to frame their own programme, to regulate their own procedure, to travel where and when they consider it necessary, and generally to operate as a fully autonomous body" (PDDE, v.119, col.1587, 9-March1950).

Government also moved to attach the IDA to the Irish legal system, which required fixing the interests of its own members in both chambers of the legislature such that they voted in favor of the IDA at each stage in the 
process, in addition to facing down the challenges posed by the opposition. Indeed, the opposition sought to win over the IDA members with its threat to abolish the organization when it returned to power. This threat required the government to make provision in the legislation to safeguard the IDA members, thereby ensuring they did not defect from the IDA actor-network. Equally, the government had to amend the proposed legislation to ensure that industrialists did not defect. With all key actors, bar the opposition, enrolled, the entire legislative process was finalized on December 13th, 1950, with the Act coming into force on December 20th, 1950.

At this point in the story, "the IDA" has gone from conception, to proposal, to decision to establish, to administrative body with members and staff, having functions and becoming attached to the entire Irish legal system in the process. The success of the translation is only possible by relentlessly sustaining the entire succession of accumulated actors, by the actors holding together and not defecting and by the actor-network enrolling sufficient actors to overcome challenges. However, though we have arrived at what appears to be a stable organization, this end point is provisional and the reality that "the IDA" has gained remains open to further transformation, as we will see. What we are already seeing is that institutional work is a materially heterogeneous process, where actors perform relationally to produce an effect we provisionally call "the IDA".

However, the IDA actor-network still faced challenges. While the IDA was granted autonomy and responsibility for most industrial policy functions, it was not granted executive authority. As such, the IDA was in the position of making recommendations to the Minister, who would then consider them before forwarding to government for consideration, this making for a cumbersome and drawn-out decision-making process. Added to this, the IDA's workload and lack of matching resources led to it becoming overworked, such that policy development lost out to administering protectionism. Different to what was required of the Department of Industry and Commerce before it, the IDA's administrative burden was made all the more cumbersome by the procedure imposed on it to closely examine each application for protection, which often involved visiting the applicant's business (GIRVIN, 1989, p.178). The IDA chairman sought increased staff and capital resources to promote new industries, along with authority to construct advance factories. Although supported by some in government (e.g., DEPARTMENT OF EXTERNAL AFFAIRS, 1950), the request was refused by the Taoiseach (i.e., Prime Minister) and the Ministers for Finance and Industry and Commerce (TAOISEACH, 1950). Thus, despite public assurances of the "fullest support" of government, the IDA was handicapped by the wide scope of its brief and a concomitant lack of resources.

On top of this, the opposition returned to government in 1951, and with them came the threat to abolish the IDA. The threat never materialized, however, as the new government's interests had also been translated in favor of keeping the IDA, having "always recognised ... that there would be some advantage in having a body outside the civil service, with powers and resources to promote the creation here of new industries" (PDDE, v.126, col.1514, 12-July-1951). Intending to use the organization now that it existed, and following discussions with the IDA's chairman to arrange how it should operate, the government decided to confine the organization's work to the promotion of new industry and to remove the burden of administrative work that had been handicapping its efforts (PDDE, v.126, col.1515, 12-July-1951). Thus, while there was potential for dissidence with the change in government, thereby bringing into question what had already been gained, the new government unburdened the IDA from the burden of administering protectionism such that it could focus on promoting new industry.

As Figure 2 (below) shows, to this point in our story, the IDA emerged as the actor-network's obligatory passage point through which to overcome the problems/obstacles the actors face in attaining what they want. Having been enlisted and defined through problematization, each actor has submitted itself to being locked into place and to being enrolled. 
Figure 2: Initial problematization - obligatory passage point and associations between actors.

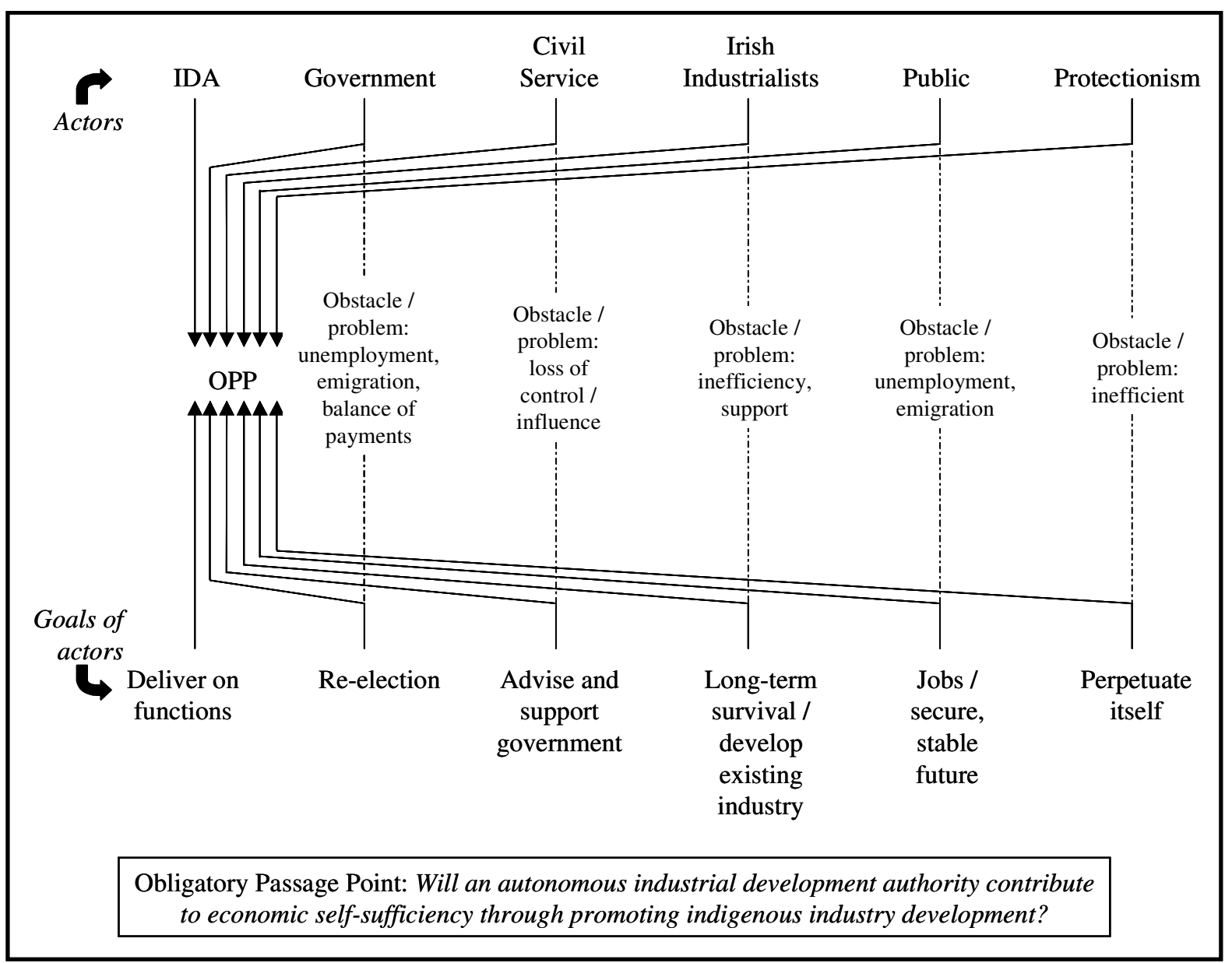

\section{Changing Tack - new problematization 1}

Initially, the IDA vigorously opposed the country's participation in the general liberalization of trade gathering pace in Europe from the late 1940s. The IDA's opposition held sway, convincing government that there was no strategy in place to progress Irish industry sufficient to withstand external competition and so justify liberalization without endangering the country's economic independence (DEPARTMENT OF INDUSTRY AND COMMERCE, 1950). However, experience on the ground was to alter the IDA's view with respect to foreign investment as a means to driving industrial development.

Narrowing the IDA's focus marked a critical move for its future development, albeit the sense of uncertainty surrounding its future also weakened it for a time (GIRVIN, 1989, p.180). While the IDA had no clear idea of its role, for much of the 1950s it was engaged in learning through doing and in building its legitimacy, credibility and influence with government and industry (GIRVIN, 1989, p.180). With little to offer in promoting new industry, the IDA attracted investment from whatever source was available, whether foreign or indigenous, in the process learning what investors required. Allied with its learning, the IDA also invested in building a good working relationship with the Minister for Industry and Commerce such that, taken together, its advice on the importance of new policies was increasingly valued. Thus, starting from a position of advocating the interests of protectionism, the IDA's view gradually changed to seeing export-led industrialization as the only way to develop the Irish economy and foreign investment as a source for such industrialization.

With challenges from the "industrial inefficiency / migration from the land / unemployment / emigration / balance of payments" hybrid persisting, and with trade liberalization growing apace outside of Ireland (e.g., General Agreement on Tariffs and Trade, European Coal and Steel Community, European Economic 
Community), the IDA emerged as a key actor and spokesperson for export-led industrialization, specifically through FDI. Defining the problem for government as the "chronic economic problems" that had defied solution over the course of 34 years of independence (PDDE, v.155, col.54-63, 7-March-1956), the IDA sought to determine and fix the interests of actors as lying in attracting FDI, with the IDA as the vehicle through which to attract such investment (see Figure 3).

Figure 3: New problematization 1 - obligatory passage point and associations between actors.

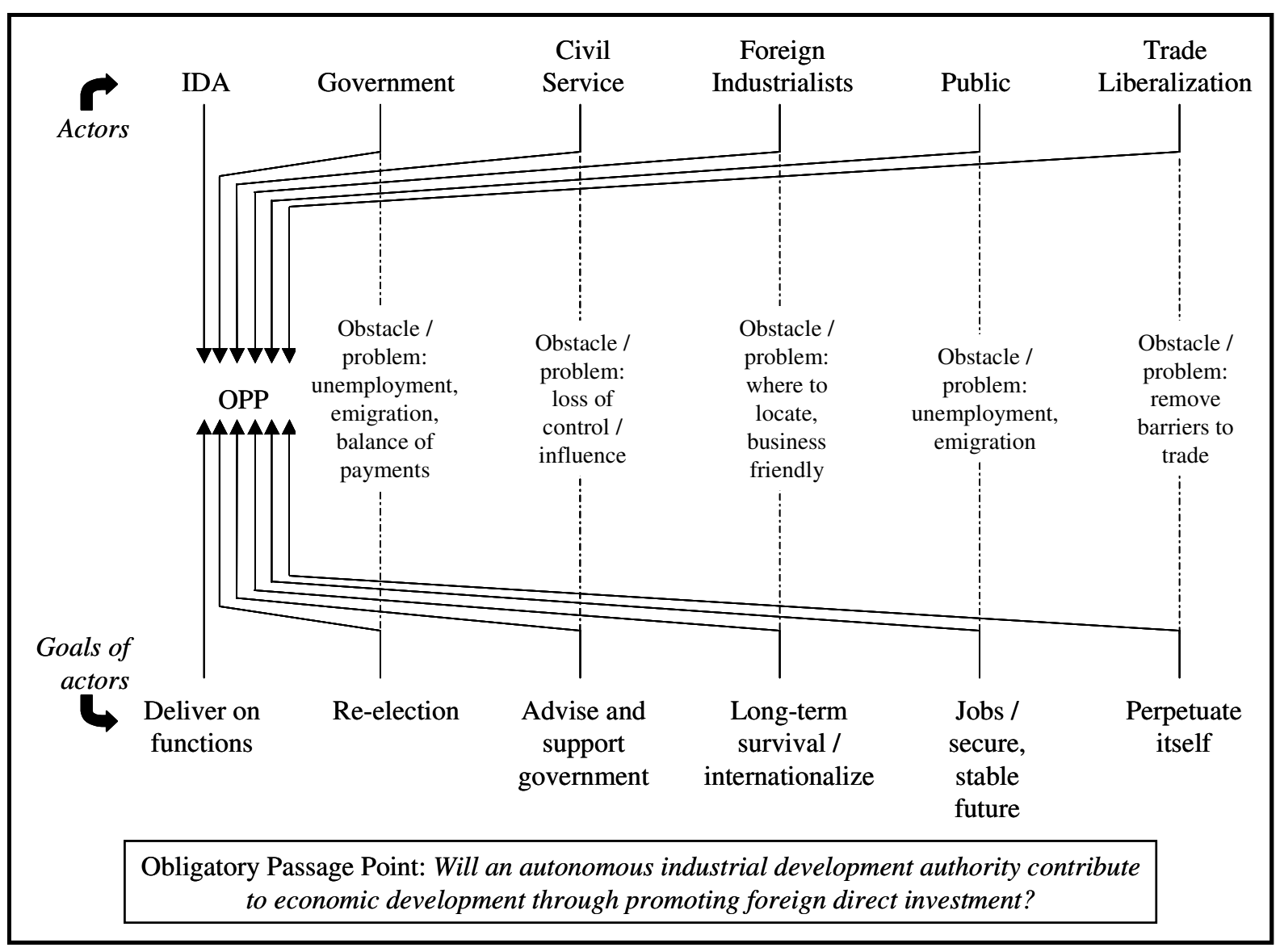

Government was slow to bite. While foreign investment was welcomed as early as 1953 (GIRVIN, 1989, p.181; PDDE, v.155, col.65-66, 7-March-1956), government was not prepared to amend the Control of Manufactures Acts, a key actor supporting protectionism, to make such investment easier (GIRVIN, 1989, p.181). It was not until various public statements in the early part of 1955 that government signaled the growing need to attract both FDI and technical competence to facilitate industrial expansion (PDDE, v.149, col.525, 23March-1955).

With government now on side, and aware that investors would "have to be wooed aggressively" (PDDE, v.152, col.1096-1097, 14-July-1955), the IDA began to actively promote the "very special advantages [Ireland had] to offer the external investor" in terms of location for ease of access to European and UK markets, trade agreements with most European countries, duty exemptions for Irish goods exported to the UK and preferential tariff treatment for Irish goods exported to British Commonwealth countries (PDDE, v.149, col.525-526, 23March-1955). 1955 saw the IDA meet with 40 companies in Sweden, 30 companies in Germany and 18 companies in Belgium (PDDE, v.155, col.46, 7-March-1956). The following year, an IDA delegation spent three weeks promoting Ireland in the US, meeting with 32 companies, bankers, representative bodies and government departments amongst others, with another delegation addressing a meeting in the Netherlands arranged by 3 Dutch employers' associations and discussion with the Federation of British industry facilitating IDA contact with British industrialists (PDDE, v.158, col.756-757, 20-June-1956). Experience with this program of visits saw the IDA open its first office in New York, staffed by its first permanent representative 
abroad, and launch its first advertising campaign towards the end of 1957 (DISPLAY..., 1957, p.11; PDDE, v.166, col.794-795, 25-March-1958).

Now enrolled in support of the IDA, government introduced export profit tax relief (EPTR) in the Finance (Miscellaneous Provisions) Act, 1956, which started at a 50 per cent reduction in taxes on export profits for a period of five consecutive years, to persuade foreign industrialists to use Ireland as an export base. The Finance Act, 1958, increased the EPTR to 100 per cent and extended the relief from five to ten years up to the year 1970. According to White (MacSHARRY; WHITE, 2000, p.246-7), at a time when the IDA had few other advantages to attract foreign investment, EPTR sent two strong messages to international business: first, that Ireland was pro-enterprise through rewarding profit; and, second, that the country favored a long-term approach to investment, as signaled by the initial (5-year) and subsequently lengthened (10-year) tax horizon.

Government also introduced further legislation to facilitate the IDA in its role of attracting FDI. Enacted in July 1958, the Industrial Development (Encouragement of External Investment) Act, brought about an easing in the restrictions on foreign ownership of industry, further signaling the government's intent to welcome foreign participation in support of driving export-oriented industrial development.

From playing a relatively passive role in support of protectionism, the IDA has now moved to being the lead actor in building a new actor-network, in the process translating the interests of, enrolling and mobilizing such actors as government, the Irish tax system, the Irish legal system, foreign industrialists, advertising, and trade agreements. Through these associations, the IDA actor-network is extended in scale and it cannot be dissociated from the other actors that hold it together and that it also holds together. In the process of building this network, the IDA is seeking to firmly place itself at the center, aligning the interests of other actors, willingly, with its own.

\section{Institutionalizing the IDA}

With tentative moves already made towards de-institutionalizing protectionism, and with the IDA firmly favoring FDI, government instituted a definitive policy shift in 1958, abandoning protectionism in favor of outward-looking economic development. This shift was rooted in two documents. The first, Economic Development (DEPARTMENT OF FINANCE, 1958a), presented a comprehensive overview of the entire economy produced by the Secretary of the Department of Finance, and head of the civil service, T.K. Whittaker, who noted:

The policies, hitherto followed, though given a fair trial, have not resulted in a viable economy. ... [L]arge-scale emigration and unemployment still persist. The population is falling, the national income rising more slowly than the rest of Europe. A great and sustained effort to increase production, employment and living standards is necessary to avert economic decadence. ... It seems clear that, sooner or later, protection will have to go and the challenge of free trade accepted. There is really no other choice for a country wishing to keep pace materially with the rest of Europe. (DEPARTMENT OF FINANCE, 1958b, p.2)

Building on Economic Development, the Programme for Economic Expansion (DEPARTMENT OF FINANCE, 1958b) concluded that achieving success would require that the state provide adequate facilities to encourage industrial development, that policies hampering industrial development be overhauled, modified or abandoned, and that foreign investment in industry, either financial or technical, be welcomed (DEPARTMENT OF FINANCE, 1958b, p.35-6).

By way of signaling the government's intent with regard to the IDA, and aligned with the IDA's interests, the Programme for Economic Expansion focused the organization's role exclusively on attracting FDI, effectively turning it into an investment promotion agency, with a clear indication to increase the organization's scope and resources should its efforts prove successful:

The Industrial Development Authority will continue the present drive to attract foreign industrial development to Ireland. Considerable success has already been achieved and it is reasonable to hope that the successful establishment and operation here of important industries financed mainly by foreign 
capital will serve as an attraction to other similar ventures. The Government attach the greatest importance to the promotional activities of the Industrial Development Authority and will be ready to widen the scope of the organisation and increase the resources at its disposal, if experience suggests the need for it. (DEPARTMENT OF FINANCE, 1958b, p.40)

Over the course of the next decade, the IDA built its position as the obligatory passage point for economic development through promoting FDI. Translating government interests for investment and jobs ensured the IDA continued to receive whatever support it needed by way of funding and incentives, in turn seeing other actors aligning with the IDA actor-network, for example, increased operational budgets; more overseas offices and representatives; a well-funded grants agency (An Foras Tionscal); the Finance Act, 1960, which extended the terminal date for EPTR at the full rate to 1974-75; the Second Programme for Economic Expansion (DEPARTMENT OF FINANCE, 1963/64), which advocated increased resources; repeal in 1964 of the Control of Manufactures Acts, 1932 to 1934, which freed the IDA's hand to pursue foreign investment in earnest; the Anglo-Irish Free Trade Agreement, signed by both governments in 1965 and coming into force on July 1st, 1966, which presented the IDA with an additional, valuable promotional tool by way of duty-free access to the UK market of 55m people; the Income Tax Act, 1967, which extended the terminal date to 1979-80.

Likewise, determining and fixing the interests of industrialists for foreign investment opportunities and supports saw yet more actors aligning with the IDA actor-network, for example, capital investment; factories; jobs; skills and training; an Industrialists Promotional Panel, consisting of leading Irish and foreign industrialists with established plants in the country, to support the IDA's work in attracting new industries through initiating contacts abroad and promoting the idea of Ireland as a location for industry (PDDE, v.230, col.1759, 26-October-1967).

What we can see here is that institutionalizing the IDA is a relational process, and that the IDA actor-network "is simultaneously an actor whose activity is networking heterogeneous elements and a network that is able to redefine and transform what it is made of" (CALLON, 1987, p.93). Equally, as the gerund suggests, institutionalizing is an ongoing process. The IDA does not arrive fully formed as a concrete and enduring structure; rather, it is created and re-created through the ongoing and dynamic interactions of the actors enrolled and mobilized to build the network. Equally, as we are seeing, we never quite arrive at a unified actor called "IDA" for long; rather we are continuously dealing with IDA hybrids, with actors being enrolled or displaced in the process of institutionalizing.

\section{Institutionalizing the IDA - new problematization 2}

By the mid-1960s, the IDA enrolled consultants Arthur D. Little (1967a, 1967b) to assist it in a major reappraisal of the program to attract foreign industry, which was the IDA's main function at that point in time (PDDE, v.222, col.1081-1082, 3-May-1966). While establishing the IDA was seen as proof of government policy to attract foreign investment, the task of persuading enough new industry to locate in Ireland to create the level of employment needed meant the IDA would also require far greater resources than were given it, in addition to the capacity and flexibility to control its own operations.

Operationally, the IDA had no control over the assignment or withdrawal of its staff, nor over its structure. Such decision-making lay with the Departments of Industry and Commerce and of Finance, an arrangement that also contributed to delays due to decisions having to be communicated through the Department of Industry and Commerce to either Finance or the IDA. This situation was deemed untenable on the grounds that the expanded role envisaged for the IDA would require the recruitment and retention of a large and specialized senior staff, a staff pool that did not exist in sufficient numbers within the civil service. Then existing staffing arrangements did not afford opportunities for internal progression within the IDA for either civil service or noncivil service staff, with both staff regimes having to seek promotion outside the IDA and the IDA losing the experience of the staff concerned.

Thus, on the one hand, the IDA was being asked to play an increasingly demanding, key role in the country's economic development, while being handicapped on the other through not having the operational autonomy to deliver on that role. Given this context, Little (1967a) recommended: 
- Giving the IDA full control over its own internal operations through granting it the status of a statesponsored organization, in addition to consolidating decision-making power concerning industrial development within the organization.

- Government pro-actively legitimize the IDA's role and position, making it clear through the reorganization legislation that both industrial development and the IDA's central role in it represented a vital, long-term program for Ireland to which it was committed.

- Consolidating incentive-making power through transferring the functions of both An Foras Tionscal (The Industry Board) and Taiscí Stáit Teoranta ([the State Investment Board] in terms of granting interest-free loans) to the IDA, effectively abolishing An Foras Tionscal and establishing the IDA as the sole interface with investors.

- The IDA build a research capability to allow for more in-depth examination of the likely success and benefit of investment projects, a capability that would also facilitate timely decision-making on large projects requiring government approval

- The IDA add expertise in advertising and promotion, research, pre-investment client handling, service and assistance, post-investment client assistance, and financing, in addition to strengthening the organization's representation abroad.

- Expanding the IDA Board, strengthening the role and office of the chairman as the organization's CEO and increasing senior staff numbers to deal with the IDA's enlarged brief.

All in all, Little (1967a) represented a blueprint that was subsequently followed in re-creating the IDA as an autonomous state-sponsored organization, charged with the key task of coordinating and delivering on Ireland's industrial development policy. Indeed, according to White (2006), it was the IDA itself that both engineered the Little review and directed its content.

Two further reviews, by the National Industrial Economic Council (1968) and the Public Services Organisation Review Group (1969), echoed and reinforced the reorganization recommended in Little (1967a), calling for the existing range of agencies dealing with industrial development to be streamlined and expertise to be concentrated within the IDA. The Third Programme for Economic and Social Development (DEPARTMENT OF FINANCE, 1969) confirmed the overhaul of the industrial development institution itself through its concentration in a more autonomous and powerful IDA, with the Industrial Development Act, 1969, enshrining what the IDA sought in legislation.

As Figure 4 (below) shows, the IDA remains as the actor-network's obligatory passage point, albeit with a subtle change, through which to overcome the problems/obstacles the actors face in attaining what they want. Having been enlisted and defined through problematization, each actor has submitted itself to being locked into place and to being enrolled. 
Figure 4: New problematization 2 - obligatory passage point and associations between actors.

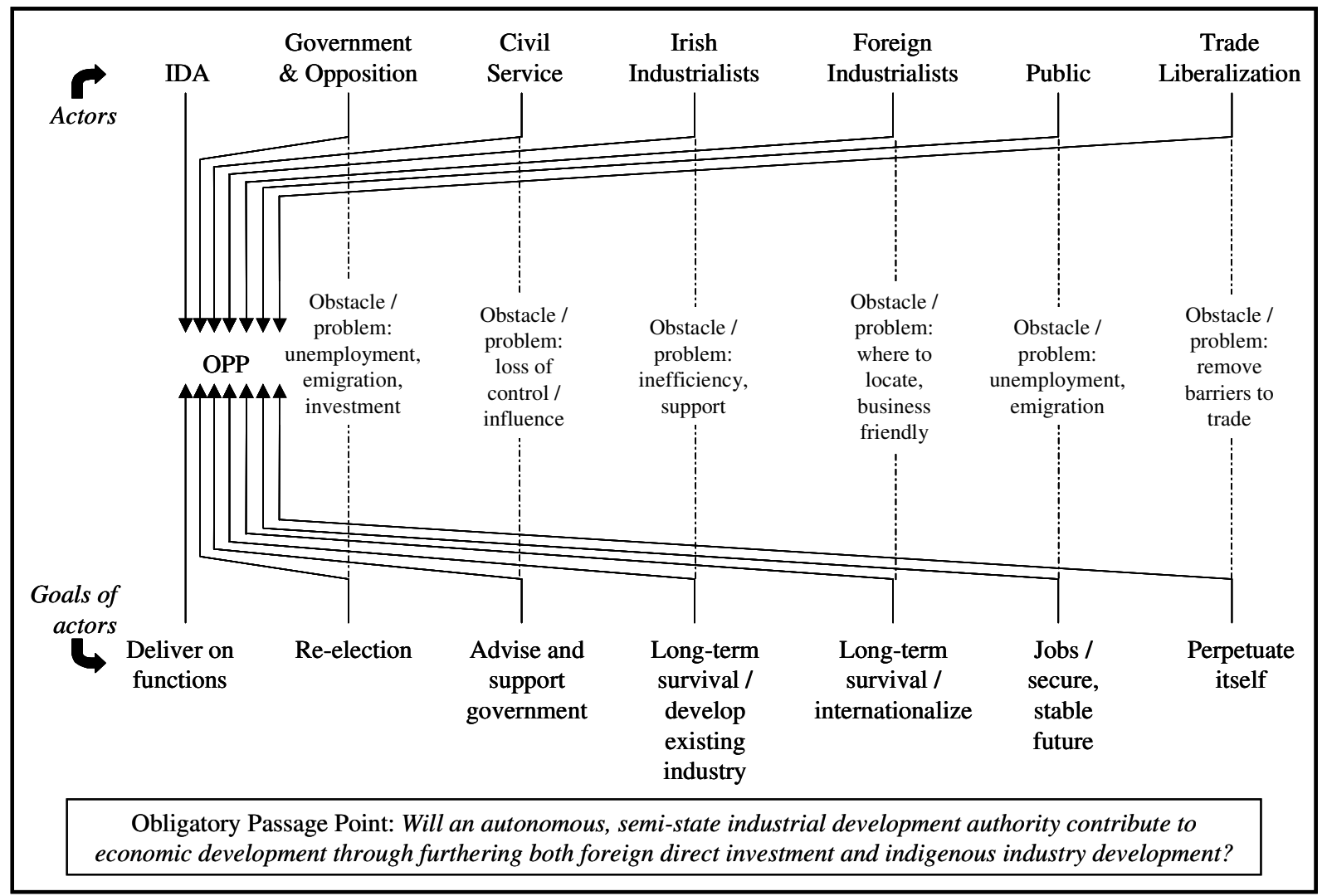

The actor "Industrial Development Act, 1969" neatly blackboxes the series of associations and substitutions comprising the IDA actor-network to this point, in the process producing a (temporary) unified IDA actor translated as "autonomous semi-state organization". However, the work of translation and hybrid-creation does not stop with the creation of this unified actor; the process of institutionalization continues.

To this actor are enrolled yet more actors, to include managing director, operational structure, committees, boards, divisions, staff, annual targets, performance reports, statistics on jobs approvals, financial commitment, fixed asset investment, strategies for picking winners, programs, reputation, promotion methods, presentations, target companies, promotional task forces, phone calls, hotels, foreign countries, advertising campaigns, promotional tours, foreign journalists, emerging sectors, industrial clustering, skilled labor, infrastructure, electronics industry, Apple, Amdahl, Microsoft, etc, etc. This extension in scale contributes to holding together the actor-network, such that, for example, investors do not defect to join some other actor-network.

Come the end of the 1970s, we are dealing with a unified actor, "IDA", which is a materially heterogeneous network of legislation, finance, FDI, indigenous industry, programs, incentives, policies, staff, public sector organizations, universities, jobs, promotion methods, advertising, organizational structures, to name but some of the actors. Blackboxing and purifying all these actors as "IDA" serves to hide them from view, but, as we have seen, the macroactor "IDA" would have no reality without all of these actors joining together in a network and performing relationally through a series of translations and hybrid-creations. The semblance of reality, of an organization we call "IDA", is not given but comes from this actor-network holding together.

According to Wickham (1983), Ireland's success in attracting FDI lay in the very particular situation of the IDA. As has already been noted, the organization was effectively the sole industrial development body in the country; it had, to this point, remained unchallenged by any power center either in the country or outside it; it was shielded from political interference that would have impacted both policy formulation and implementation; its "discretionary" decision-making was suited to dealing with private enterprise; and it was in a position to legitimate itself to both the public and its own staff as fulfilling an important national task. 
While Wickham's observation points to success with foreign investment, the same success was not achieved with domestic industry, which had not been fully enrolled. Having experienced a decade of relative glory through the 1970s, the organization's legitimacy came into question on foot of the Telesis (1982) review and at a time when the country was experiencing the effects of a global recession, a poor foreign investment climate, mounting domestic economic problems and increasing unemployment (IDA, 1980-1983; MacSHARRY; WHITE, 2000; TELESIS, 1982).

\section{Questioning the IDA's legitimacy}

The unified actor "IDA", which is now much bigger in scale than at any other point in our story, is challenged by a crisis at the start of the 1980s that sees the IDA's legitimacy questioned. While reliance on FDI had found general acceptance and largely went unquestioned, concerns nonetheless gradually emerged throughout the 1970s about an over-reliance on such investment and its tenuous links with the economy, not to mention a dualistic industrial structure and the influence of external interests on national sovereignty (e.g., COOPER; WHELAN, 1973; JACOBSEN, 1978; KENNEDY; DOWLING, 1975; LONG, 1976; PDDE, v.242, col. 234748, 28-November-1969; PDDE, v.286, col.633-634, 2-December-1975; STANTON, 1979; WOOING..., 1977).

One critic, Dr. Noel Whelan (of COOPER; WHELAN, 1973), ended up in a position to initiate a review of industrial policy when he took over as chairman of the National Economic and Social Council (NESC) in 1978 (PDDE, v.317, col.573, 4-December-1979). His position as NESC Chairman was all the stronger due to the fact that he was also Secretary of the Department of Economic Planning and Development (1977-79) and then Secretary of the Department of the Taoiseach. Under his chairmanship, the NESC decided to commission a review to ensure that government industrial policy was suited to creating an internationally competitive industrial base in Ireland (NESC, 1982, p.iii).

In conducting its review, the NESC sponsored a five-part study, the first of which (O'MALLEY, 1980) comprised a survey of literature and of changes in Irish industrial policy over the period from the early 1960s. The second (FOSTER et al, 1981) evaluated the state's physical infrastructure and its impact in hampering existing industry and acting as a barrier to attracting new industry. The third (BLACKWELL; DANAHER; O'MALLEY, 1983) analyzed the extent and nature of job losses in industry. The fourth (TELESIS, 1982) evaluated Irish industrial policy and the fifth (NESC, 1982), in bringing together the analyses of the four previous studies, set out conclusions and broad recommendations on industrial policy. The government responded to the Telesis (1982) and NESC (1982) reports with the first ever White Paper on Industrial Policy published in 1984.

The Telesis (1982) report had the greatest impact of all in regard to the IDA and to industrial development policy. In assessing the state's then industrial policy, the review was complimentary on a number of fronts. Notwithstanding the considerable national effort to industrialize over the preceding thirty years, the review's main criticism was that industrial development had largely depended on FDI, while indigenous industry languished. Despite statements pointing to the importance of indigenous industry, the allocation of resources told a different story: funding for indigenous industry amounted to one-third of all funding available, a proportion that remained stable over the preceding decade, with actual funds disbursed only increasing slightly in real terms, even though there were major real increases in IDA budgets.

While Telesis (1982, p.242) stated it was "positively impressed with Irish industrial policy goals and implementation" and that its recommendations were "designed to improve an already excellent effort", a different story emerged in the national media, wherein the IDA was slammed for its poor performance in developing indigenous industry and for touting job approvals as its metric of success over jobs actually created. The report was leaked through the media in August 1981, with Irish Business (TELESIS..., 1981) making its content public for the first time in an article headed "Telesis: An Indictment of Irish Industrial Policy". Newspaper reports presented Telesis as highly critical of the IDA:

More than 67,000 jobs paid for by State grants by the Industrial Development Authority have failed to materialise, according to a Government-commissioned report. And the IDA - the biggest spending State agency in the country - has been indicted as a 'failure' in the report carried out by American 
consultants. ... The report...places a serious question mark over the operations of the IDA and recommends that the money it receives from the Government be cut back and diverted to other bodies. (AUGHNEY, 1981, p.1)

Criticism leveled at the IDA by members of the Oireachtas was negligible, indicative of the level of support enjoyed by the organization not only of successive governments, but also of the political establishment. Government came to the defense of the IDA. The Taoiseach of the time, Garret Fitzgerald, pointed to the failures of indigenous industry to prepare for liberalized markets, despite government and IDA help to adapt to new conditions (PDDE, v.342, col.838-839, 11-May-1983). The Tánaiste (i.e., Deputy Prime Minister) of the time, Dick Spring, pointed to the continuity of industrial policy over successive governments since the late 1950s and observed that the IDA was not to blame for the weaknesses identified by Telesis; rather it was a problem of an inadequate policy framework (PDDE, v.342, col.861, 11-May-1983). For its part, the IDA believed the overall impact of Telesis was harmful, with many of its core recommendations considered "reckless", and saw Telesis as an attempt by certain interests to substantially neuter the IDA (WHITE, 2006).

Nonetheless, the organization acknowledged acceptance of many Telesis recommendations and indicated that it was already dedicating more effort to encouraging more companies to export and to bolstering the indigenous industrial base (SNODDY, 1982, p.31). Then managing director, White, emphasized the continuity of industrial policy and considered that programs would not be cancelled and that existing policies would not be reversed (SNODDY, 1982, p.31). As Keenan (1984, p.23) noted, the "IDA is not just good at promoting jobs; it is a remarkably flexible organisation with a proven ability to respond to changes in the economic climate and maintain its position as the pivotal organisation in development strategy".

Representing its response to Telesis (1982) and NESC (1982), and incorporating many of the recommendations contained in the IDA's 1983 Strategic Plan, the government published its White Paper on Industrial Policy (GOVERNMET OF IRELAND, 1984) to cover the decade ahead. The major change implied in the White Paper was not to the IDA nor was it to the general system of incentives; rather it was to the selective manner in which the incentives were to be applied. The new policy orientation involved little change with regard to foreign investment, albeit more emphasis was placed on attracting projects where key functions, such as marketing and $\mathrm{R} \& \mathrm{D}$, would be performed, in addition to projects that would allow for development of linkages to the Irish economy.

The White Paper (GOVERNMENT OF IRELAND, 1984) recognized the significant contribution of the foreign sector to the country's economic development. It echoed the concerns of both the NESC (1982) and the IDA in asserting that there would be no "sudden or radical" changes to the incentives for foreign investment. Indeed, the government's stated position was that

[t]he consistency and stability over many years of our policies for industrial development have been a major source of strength. Changes in Government have not resulted in major reversals of policy as has happened in other countries. There has always been a favourable Government attitude towards investment in Ireland by foreign industry. (GOVERNMENT OF IRELAND, 1984, p.7)

As such, the overall impact of Telesis was to refine both the IDA and industrial development policy, with the IDA still very much the lead industrial development organization. The outcome of Telesis and the debate it engendered was the setting of an adjusted course, building on past success and reflecting the lessons learned from experience gained to that point. While the IDA was seriously questioned, potential dissidence was avoided through government and opposition remaining aligned to the IDA actor-network, along with foreign investors.

\section{De-legitimizing and de-institutionalizing the IDA?}

The early 1990s witnessed yet another review of industrial policy. The Industrial Policy Review Group (IPRG, 1992), amongst other things, concluded that attracting foreign investment is a fundamentally different activity to developing indigenous industry and that the then existing configuration of agency structures was not satisfactory. Thus, the IPRG recommended the creation of separate organizational arrangements, with one state 
agency handling overseas investment promotion, primarily a marketing and selling task, while integrating all existing supports and agencies for indigenous industry into another agency, which would play more of an advisory and consultancy role.

While the government accepted the IPRG recommendations and the subsequent Moriarty Task Force implementation program, the recommendation to restructure the IDA into two separate organizations emerged as the most contentious of all (TAYLOR, 1992, p.11), with competing actor-networks emerging to define the problem and the program for dealing with it. In support of restructuring the IDA were the IPRG, most of the members of Moriarty Task Force, the Department of Enterprise and Employment (formerly Industry and Commerce), its minister, Desmond O'Malley, and his minority government party, the Progressive Democrats.

The IDA argued strongly that splitting up the organization would impede building links between indigenous and foreign industry and lobbied steadfastly to have the strategy changed in favor of a single organization encompassing all state supports to both overseas and indigenous industry (TAYLOR, 1992, p.11). The majority government party, Fianna Fáil, was against the creation of separate agencies, preferring to accommodate the restructuring within the existing IDA, which was already organized along separate indigenous and overseas lines. The largest of the opposition parties, Fine Gael, also voiced its objections to splitting the IDA into two separate organizations and urged that the proposed restructuring retain the IDA intact (CULLITON..., 1992). Two Moriarty Task Force members voiced disagreement with the split: the Director of the Economic and Social Research Institute dissented from the recommendation, while then Secretary of the Department of Finance, partly concerned at the cost implications of funding two separate organizations, considered that the restructuring could be accommodated within a single agency.

What emerged from the tussle was a hybrid proposal creating two separate agencies, as the IPRG recommended, but with the addition of an umbrella agency having a coordinating role in promoting greater linkages between indigenous and foreign industry and an advisory role on the development and coordination of policy within which the two agencies operate. The negotiation of a compromise between the major and minor government parties was sufficient to enroll the major government party to the program to split the IDA and so see blackboxing of the policy review actor-network as concerns the IDA in the Industrial Development Act, 1993. Thus it was that the policy refocus recommended from Telesis (1982) onwards found subsequent expression in the formal recreation of the IDA as three separate actors: Forfás, the umbrella organization; Forbairt (now Enterprise Ireland), the indigenous industry organization; and IDA-Ireland, the overseas investment organization.

\section{In conclusion...what an actor-network theory analysis illustrates and affords}

As the ANT analysis illustrates, institutionalization is both contingent and emergent. It is contingent in the sense that it is never fixed for all time, for the actor-network could come asunder should any of the actors defect. And it is emergent in the sense that the actor-network does not appear ready formed, as a pure essence that always-already existed.

The only essence of the IDA actor-network is its total existence (LATOUR, 1991). Looking through the lens provided by ANT shows that institutionalization is never quite static, never quite reified; rather the IDA blackbox is opened and re-negotiated throughout the story, albeit the opening and re-negotiating often entailed the enrolling and mobilizing of yet more actors to the IDA actor-network. As such, no one particular part of the actor-networks being constructed is the essence of the IDA, with all the other parts being merely context or packaging or history.

What we see through following the actors is the work of translation and hybrid-creation, which goes unacknowledged in the more traditional renderings of the institutional. Through following such work, we see that institutionalization is an ongoing process and that, in this case, it was rare that we arrived at a unified, blackboxed actor. Even then, the actor so purified was contingent and open to further translation. What we see is that institutionalization is a process of building associations, of materially heterogeneous actors performing relationally. Arriving at a (contingently) stable actor is to arrive at such a materially heterogeneous actornetwork holding together such that it can be (temporarily) blackboxed and named. 
Echoing Lawrence and Suddaby (2006), amongst others, and linking with the concerns noted by Clegg and Machado da Silva (2009), I posit that ANT, as a theoretical and analytical approach, holds promise in addressing the drawbacks of existent approaches to institutional work. Of particular interest to this discussion is the re-articulation of institutional work as a constructivist endeavor (LATOUR, 2002) and the intellectual contribution an actor-network approach offers by way of viewing institutionalization as relational performance, translation and power as product, away from the field's focus on reification, diffusion and power as property. 


\section{References}

AKRICH, M.; LATOUR, B. A summary of convenient vocabulary for the semiotics of human and non-human assemblages. In: BIJKER, W.; LAW, J. (Ed.). Shaping technology, building society: studies in sociotechnical change. Cambridge, MA: MIT Press, pp.259-64, 1992.

AUGHNEY, J. I.D.A.'s 67,000 'phantom' jobs. Irish Independent, p.1, 6 Aug. 1981.

BLACKWELL, J.; DANAHER, G.; O'MALLEY, E. An analysis of job losses in Irish manufacturing industry. Dublin: Stationery Office, (NESC Report n.67), 1983.

CALLON, M. Some elements of a sociology of translation: domestication of the scallops and the fisherman of St. Brieuc Bay. In: LAW, J. (Ed.). Power, action and belief: a new sociology of knowledge? London: Routledge, 1986. pp.196-233, 1986.

Society in the making. In: BIJKER, W.; HUGHES, T.; PINCH, T. (Ed.). The social construction of technological systems. Cambridge, MA: MIT Press, pp.83-103, 1987.

; LATOUR, B. Unscrewing the big Leviathan. In: KNORR-CETINA, K.; CICOUREL, A. (Ed.). Advances in social theory and methodology: toward an integration of micro-and macro-sociologies. New York, NY: Routledge, pp.288-303, 1981.

CLEGG, S.; MACHADO DA SILVA, C. L. Power, organizations and institutional change. 2009. Available at: <http://www.egosnet.org/jart/prj3/egosnet/main.jart?rel=en\&content-id=1252389566424\&reserve-mode=active>. Access: 30 Apr. 2010.

COOPER, C.; WHELAN, N. Science, technology, and industry in Ireland: report to the National Science Council. Dublin: Stationery Office, 1973.

COOPER, R.; LAW, J. Organization: Distal and proximal views. In: BACHARACH, S. B.; GAGLIARDI, P.; MUNDELL, B. (Ed.). Research in the sociology of organizations: studies of organizations in the European tradition. Greenwich, CT: JAI Press, pp.275-301, 1995.

CULLITON task force to propose wide reforms. Irish Times, p.12, 21 July 1992.

DEPARTMENT OF EXTERNAL AFFAIRS. Memorandum for the government - Industrial Development Authority. Dublin: National Archives of Ireland. File: Taoiseach S.14474A (9 November), 1950.

DEPARTMENT OF FINANCE. Economic development. Dublin: Stationery Office, 1958a.

Programme for economic expansion. Dublin: Stationery Office, 1958b.

Second programme for economic expansion. Dublin: Stationery Office, 1963/64.

Third programme for economic and social development, 1969-72. Dublin: Stationery Office, 1969.

DEPARTMENT OF INDUSTRY AND COMMERCE. Memorandum for the government - Havana Charter for an International Trade Organisation. Dublin: National Archives of Ireland, File: Taoiseach S.13915B (6 April), 1950.

DISPLAY ad: Ireland welcomes your industry! Wall Street Journal, p.11, 16 Dec. 1957.

FOSTER, C. D. et al. The importance of infrastructure to industrial development in Ireland: roads, telecommunications and water supply. Dublin: Stationery Office, (NESC Report n.59), 1981.

GIRVIN, B. Between two worlds: politics and economy in independent Ireland. Dublin: Gill and Macmillan, 1989.

GOVERNMENT OF IRELAND. White paper on industrial policy. Dublin: Stationery Office, 1984.

IDA - Industrial Development Authority. Annual reports. Dublin, 1980-1983.

IPRG - Industrial Policy Review Group. A time for change: industrial policy for the 1990's. Dublin: Stationery Office, (The Culliton Report), 1992.

JACOBSEN, J. K. Changing utterly? Irish development and the problem of dependence. Studies: an Irish Quarterly Review, v.67, n.268, pp.276-91, 1978.

KEENAN, B. Strategy reappraised. Financial Times, p.23, 2 July, 1984.

KENNEDY, K. A.; DOWLING, B. R. Economic growth in Ireland: the experience since 1947. Dublin: Gill and Macmillan, 1975. 
LATOUR, B. The powers of association. In: LAW, J. (Ed.), Power, action and belief: a new sociology of knowledge? London: Routledge \& Kegan Paul, pp.264-80, 1986.

Technology is society made durable. In: LAW, J. (Ed.). A sociology of monsters? Essays on power, technology and domination. London: Routledge, pp.103-31, 1991.

We have never been modern. Cambridge, MA: Harvard University Press, 1993.

Pandora's hope: essays on the reality of science studies. Cambridge, MA: Harvard University Press, 1999.

The promises of constructivism. 2002. Site: <http://www.bruno-latour.fr/articles/article/087.html>. Access: 30 Apr. 2010.

LAW, J. Notes on the theory of the actor-network: ordering, strategy and heterogeneity. Systems Practice, v.5, n.4, pp.37933, 1992. Site: <http://www.lancs.ac.uk/fass/sociology/papers/law-notes-on-ant.pdf>. Access: 30 Apr. 2010.

After ANT: complexity, naming and topology. In: ; HASSARD, J. (Ed.). Actor - network theory and after. Keele: Blackwell Publishers/The Sociological Review, pp.1-14, 1999.

; HETHERINGTON, K. Materialities, spacialities, globalities. Department of Sociology, Lancaster University, 1999. Site: <http://www.lancs.ac.uk/fass/sociology/papers/law-hetherington-materialities-spatialities-globalities.pdf>. Access: 30 Apr. 2010.

LAWRENCE, T. B.; SUDDABY, R. Institutions and institutional work. In: CLEGG, S. R. et al. (Ed.). The handbook of organization studies. $2^{\text {nd }}$ ed. London: Sage, pp.215-54, 2006.

LEE, J. J. Ireland 1912-1985: politics and society. Cambridge: Cambridge University Press, 1989.

LEE, N; HASSARD, J. Organization unbound: Actor-network theory, research strategy and institutional flexibility. Organization, v.6, n.3, pp.391-404, 1999.

LITTLE, A. D. Review of the structure of the Industrial Development Authority. Dublin: Industrial Development Authority, 1967a.

Review of incentives for industry in Ireland. Dublin: Industrial Development Authority, 1967b.

LONG, F. Foreign direct investment in an underdeveloped European economy: the Republic of Ireland. World Development, v.4, n.1, pp.59-84, 1976.

MacSHARRY, R.: WHITE, P. The making of the Celtic tiger: the inside story of Ireland's boom economy. Cork: Mercier Press, 2000.

MURDOCH J. Actor-networks and the evolution of economic forms: combining description and explanation in theories of regulation, flexible specialization, and networks. Environment and Planning A, v.27, n.5, pp.731-57, 1995.

NATIONAL INDUSTRIAL ECONOMIC COUNCIL. Report on industrial adaptation and development. Dublin: Stationery Office, (NIEC Report n.23), 1968.

NESC - National Economic and Social Council. Policies for industrial development: conclusions and recommendations. Dublin: Stationery Office, (NESC Report n.66), 1982.

O'MALLEY, E. Industrial policy and development: a survey of literature from the early 1960's to the present. Dublin: Stationery Office, (NESC Report n.56), 1980.

PDDE - Parliamentary Debates of Dáil Éireann. 1919-2009. Site: <http://historical-debates.oireachtas.ie/index.html>. Access: 30 Apr. 2010.

PUBLIC SERVICES ORGANISATION REVIEW GROUP. Report of Public Services Organisation Review Group 19661969. Dublin: Stationery Office, (The Devlin Report), 1969.

SAHLIN-ANDERSSON, K. Imitating by editing success: the construction of organizational fields. In: CZARNIAWSKA, B.; SEVÓN, G. (Ed.). Translating organizational change. Berlin: Walter de Gruyer, pp.69-92, 1996.

SNODDY, R. How the IDA is acting as a matchmaker. Financial Times, p. 31, 16 Apr. 1982.

STANTON, R. Foreign investment and host-country politics: the Irish case. In: SEERS, D.; SCHAFFER, B.; KILJUNEN, ML. (Ed.). Underdeveloped Europe: studies in core-periphery relations. Hassocks: Harvester Press, pp.103-23, 1979.

STRUM, S.; LATOUR, B. The meanings of the social: from baboons to humans. Social Science Information, v.26, pp.783802, 1987. 
TAOISEACH. Memorandum to the Minister for External Affairs. Dublin: National Archives of Ireland. File: Taoiseach S.14474A (14 November), 1950.

TAYLOR, C. O'Malley backs Culliton plan: Ahern and Authority are opposed to split. Irish Times, p.11, 28 July 1992.

TELESIS: an indictment of Irish industrial policy. Irish Business, p.7, Aug. 1981. 1982.

- The Telesis Consultancy Group. A review of industrial policy. Dublin: Stationery Office, (NESC Report n. 64),

TOLBERT, P.; ZUCKER, L. G. The institutionalization of institutional theory. In: CLEGG, S. R.; HARDY, C.; NORD, W. R. (Ed.). The handbook of organization studies. London: Sage, pp.175-90, 1996.

TOURAINE, A. The return of the actor. Minneapolis, MN: University of Minnesota Press, 1988.

WICKHAM, J. Dependence and state structure: foreign firms and industrial policy in the Republic of Ireland. In: HÖLL, O. (Ed.). Small states in Europe and dependence. Vienna: Braumüller, pp.164-83, 1983.

WHITE, P. Personal interview. 9 May 2006.

WOOING the foreigner. The Economist, p.13, 9 Apr. 1977. 